\title{
On the Reasons of the Tragedy of the Great Poet Li Yu
}

\author{
Zhong-hua LI ${ }^{1, a,{ }^{*}}$ \\ ${ }^{1}$ College of Humanities and Social Sciences, Henan Institute of Engineering, Henan \\ 451191, Zhengzhou, China \\ alindalee2009@yeah.net,
}

Keywords: Li Yu, Tragedy of life, Autocratic monarchy, Literary character.

\begin{abstract}
Li Yu was a brilliant poet, and also the emperor of a declined kingdom. In the history of China, there were not many people who have the dual identity of an emperor as well as an outstanding writer. The poet has the character of honor and easy-going, but the emperor usually is good at scheming and calculating. Acting as an emperor as well as a poet, two roles conflicted and incompatible like water and fire, the idle poet $\mathrm{Li} \mathrm{Yu}$ came to throne succeeding his father Zhongzhu Li Jing and ended up with his country eliminated and he himself perished. The first reason for the tragedy of Li Yu's life is the feudal autocratic monarchy. The second is the Li Yu's character and ability. Li Yu's character was obviously a literary character. Li Yu had a strong literary interest and profound literary accomplishment.
\end{abstract}

\section{Introduction}

In the history of China, there have been not many people who had the dual identity of the emperor and the outstanding writer. The famous poet $\mathrm{Li} \mathrm{Yu}$ of the Dynasty of Nantang carried this dual identity of both the emperor and the outstanding writer. $\mathrm{Li} \mathrm{Yu}$ was versatile, having a certain degree of accomplishment in calligraphy, painting, music and other aspects, especially having the highest achievements in ci. He asserted a profound impact on future generations in the creation of ci. But Li Yu was also a tragic figure. After his country was fallen he was taken a prisoner, suffered the extreme humiliation, and was poisoned to death at the age of 42 .

The author believes that the reasons for the tragedy of Li Yu's life are the following:

\section{The Reason of Feudal Autocratic Monarchy}

Li Yu's grandfather Li Bian (Xu Zhigao) was an orphan in the late Tang Dynasty, taken in by warlord Yang Xingmi, and later sent to Xu Wen as his adopted son. Xu Wen was a powerful courtier of the Yang $\mathrm{Wu}$ regime. After the death of $\mathrm{Xu}$ Wen, Li Bian (Xu Zhigao) as his adopted son came into power as the prime minister of Wu Country, grasping the military and political power of $\mathrm{Wu}$ into his own hand. Later Li Bian proclaimed himself the Grand Prime Minister, the Grand Marshal, deposed the Emperor of Wu Country, and established the Great Tang Dynasty which is called the Nangtang Dynasty in Chinesee history. As Xu Wen's adopted son, Li Bian was envied Xu Wen's sons extremely. They schemed to destroy Li Bian repeatedly, but did not succeed. As Li Bian was born of humble origins and in the time of wars, lived through difficulties and hardships, and knew the difficulties of getting the regime and ruling the world, he didn't love a frugal life. Instead he lived a hard, diligent life, regarded by commentators as an excellent monarch. The next monarch Li Jing, the son of Li Bian could not act as well as his father as a ruler. Li Jing lived in extravagance, leading to political corruption and national decline. Although he was a excellent man of literature and wrote the famous 
sentence "the jade Sheng blew through the cold small building", the country began to decline day by day. Under the threat of the Later Zhou Dynasty Li Jing himself removed the title of Emperor and renamed himself as the Ruler of the Southern Yanyzi River.Li $\mathrm{Yu}$, born in the palace, and grown in the hands of women, was the third generation of the Nantang Dynasty. Li Yu did not know how difficult the crop-growing is, the governance of a country is, neither did he know the basics of military affairs. So in the reign of Li Jing ( $\mathrm{Li}$ Yu's father) there were courtiers who thought that $\mathrm{Li} \mathrm{Yu}$ was not suitable for the future Emperor. Many later commentators have criticized Li Yu. Mao Zedong said: "Although the Southern Tang Emperor Li Yu was versatile, he did not pay much attention to politics, so he was finally conquered." Ou Yangxiu of the Song Dynasty said: "Li Yu lived in arrogant extravagance, loved music and beautiful women, and extremely interested in Buddhism. As to politics, he did not pay much attention". Even if there was some commentator who said something in favor of $\mathrm{Li} \mathrm{Yu}$ he would also criticized Li Yu. Lu You of the Song Dynasty said " Li Yu loved Buddhism, worshiped towers and temples of Buddhism, and let numerous men and women be monks and nuns. After working Li Yu made many many Buddha houses, changed his clothes to worship Buddha, so he wasted a lot of energy and a huge amount of government money.Although Li Yu did not have the talent of running the country, he was chosen by his father and came to the throne in a smooth succession. The feudal autocratic monarchy had been practiced in China for thousands of years, the emperor having the country as their own property, and the peace and well-being of the working people was not the emperor's top concern. The extravagant life style of the regal family and the passing on of the throne from generation to generation was the primary consideration of the emperor. Li Yu as the son of Li Jing, regardless of his capacity to ruling the country, are very likely to inherit the throne. This is really a tragedy. Because the tragedy happened to regal family, it also affected the life of thousands of thousands families. Countless soldiers were to serve as cannon fodder on the battlefield for the two dynasties of the North Song and the South Nantang. Feudal autocratic system not only caused the tragedy of the emperor and the emperor's family, but also caused the tragedy of countless ordinary people.

\section{Reasons of Character and Ability}

Born in the palace, raised and pampered by woman's hands, growing up in a easy life, without tempered by the difficulties and hardships of the low life, $\mathrm{Li} \mathrm{Yu}$ was indeed a master in extravagant life, enjoying the melody and lyrics and paintings, but he was a meddle-headed Emperor in running the country is. The home affairs of the country had shown a growing momentum of political chaos in the period of Li Yu's father Li Jing. With Li Yu stepping up to the throne, the new contention and collision between parties of the courtiers began growing. When invasion and circling around by the central plains Dynasty who worked together with the Dynasty of Wu Yue of the south became tighter and tighter, the political friction in the Nantang court showed no slight sign of abation. $\mathrm{Li} \mathrm{Yu}$ was a master in literature, painting, music, but he apparently was not proficient in politics and was not willing to put his heart in the running of the country. He entrusted his government to his courtier Zhang ji who had been his chief of staff when he was Crown Prince. After Zhao Kuangyin wiped out Nanhan, stated his troops in Hanyang, and detained Li Yu's brother Li Congshan, Li Yu was panic anomaly. But facing the urgent situation, Li Yu did not dare to burning northern warships secretly. What he could do was only to drink wine every day to relieve sorrow. All these things and performances showed that the character of $\mathrm{Li} \mathrm{Yu}$ who was a master in literature, music, 
painting and calligraphy etc., but not in politics and military affairs. Li Yu could have been a good conservative monarch if he were born in a time of national peace and order, but in times of battles and wars, Li Yu's good character obviously could not meet the requirements of his nation and his family.

It is said that $\mathrm{Li} \mathrm{Yu}$ is the inventor of women's foot binding. This showed clearly that $\mathrm{Li} \mathrm{Yu}$ was a women's man and he played many a woman in his life. Li Yu also wrote down his own experiences with women into his literary works.

These works have a certain artistic value, but comparatively Li Yu's works of his later life have more art value. "The beautiful lady Yu" which is selected into a variety of textbooks is the representative work of Li Yu's later creation. The whole work does not use embellishment and allusions. All it uses is drawing technique. "When will there be more antumn moon and spring flowers/For me who had so many memorable hours?" This sentence is Li Yu's memories of the past. In his days when he was emperor he indulged in debauchery, was surrounded by countless beauties, lived a gay life. " The east wind blew again in my garden last night,/How can I bear the cruel memory of bowers/ And palaces steeped in moonlight!" Now spring comes again, but the past emperor life could not become a reality again. " Carved balustrades and marble steps must still be there,/But rosy faces cannot be as fair."" beauties "refers to the girls who in the past served $\mathrm{Li} \mathrm{Yu}$." only " is a word of infinite grief. If only $\mathrm{Li} \mathrm{Yu}$ had known today's result, he would not have indulged in debauchery and abandoned the court affairs. The last sentence " If you ask me how much my sorrow has increased,/Just see the over-brimming river flowing east!" highlights "depression", connecting the words before and after, making the work a whole. This poem broke through entertainment tradition of the Tang and Five Dynasties Ci creation, using $\mathrm{Ci}$ to to express feelings and to sing the sorrows of life. It was appreciated as a song of blood and tears, and every word of it is called a word of enormous value.

Li Yu's character can be said to be a typical literary personality. First of all, Li Yu has a strong literary interest and profound literary accomplishment. According to History of Ten Countries, because Li Yu looked like an emperor, Crown Prince Li Hongji was jealous of $\mathrm{Li} \mathrm{Yu}$. In order to avoid arousing suspicion, Li Yu put all his energy into classic books. By and by, in the reading of these classic books Li Yu cultivated his interest in literature. During this period Li Yu wrote the poem A Fisherman's Poem:

White-crested waves aspire to a skyful of snow;

Spring displays silent peach and plum trees in a row.

A fishing rod,

A pot of wine,

Who in this world can boast of happier life than mine?

This poem clearly shows Li Yu's obsession with literature and the poet's literary accomplishment. It can be inferred that at this time $\mathrm{Li} \mathrm{Yu}$ had drawn a conclusion that he would have to keep far away from politics, that he would have to be a scholars in literature, which would be the field he could give his talent the full play. However, God's giant hand has a strange way to deal with human affairs and push $\mathrm{Li} \mathrm{Yu}$ to the emperor's position, causing the poet's misfortune. His misfortune in its turn made him able to create wonderful poems which enriched Chinese literature and Chinese culture greatly.

Being a prince and later an emperor provided Li Yu with time and energy, with many conditions to lay his hand on Chinese cultural classics and to appreciate these classics. As a result, $\mathrm{Li} \mathrm{Yu}$ became a master in literature. The history books say that Li Yu had a very large library, and that he spent a large amount of money to purchase tens of 
thousands of volumes of books in the palace. Had Li Yu been no prince, no emperor, but a common person, he would have been unlikely to have the time and energy to achieve such a high literary accomplishment.

A man who has a real interest in literature will never become a tyrant. In the cultivation of literature, a man's heart became subtle and deep and kind. The high literature accomplishment not only made the appearance and action of $\mathrm{Li} \mathrm{Yu}$ gentle and elegant, but also made his heart courtly and gentle. Li Yu the Emperor showed a great deal of generosity and kindness. Every time Li Yu faced the death penalty he would suffer to tears. Li Yu was obsessed with Buddhism, to the extent of abandoning political affairs. This was later criticized by many people many times. But this is also a sign of his generosity and kindness. Comparing Li Yu with Song Daojun emperor, Wang Guowei said wisely that the poems of Song Daojun emperor only vented out his feelings of life, but the creation of LI Yu expressed the heart and courage of Buddha and Christ. Song Daojun emperor and $\mathrm{Li} \mathrm{Yu}$ were in different levels of literary achievement.

Li Yu regarded literature as life. Confucius said: those who know are better than those who love, those who are obsessed are better than those who love. From the literary point of view, the meaning of this sentence is that people who understand literature is not as good as people who love literature, people who love literature is not as good as people who are obsessed with literature. Li Yu not only understood literature, but also loved literature. He not only loved literature, but was also obsessed with literature. He was nit only obsessed with literature but also regarded literature as the purpose and meaning of life.

$\mathrm{Li} \mathrm{Yu,} \mathrm{who} \mathrm{came} \mathrm{to} \mathrm{the} \mathrm{throne,} \mathrm{was} \mathrm{facing} \mathrm{a} \mathrm{severe} \mathrm{situation.} \mathrm{The} \mathrm{Northern} \mathrm{Song}$ Dynasty Zhao regime was all the time thinking of the demise of the southern tang. In such a situation, Li Yu should put all his time and effort into governance, but this was not the case. In the domestic trouble and foreign invasion $\mathrm{Li} \mathrm{Yu}$ always did not forget the creation of poems. Almost all kinds of events experienced by $\mathrm{Li} \mathrm{Yu}$ were reflected in Li Yu's poems. The funeral oration after the death of the Empress Zhou, the poems after his younger brother were taken hostage, the creations when he was arrested and driven to North, the poems written when he was under house arrest in Kaifeng, the capital of the North Song Dynasty, etc., showed that Li Yu wrote in his leisure as well as when his country was badly in need of good governance. When he should intense attention to deal with the enemy he was still engaged in the creation of literature. The obsession with literature and a great deal of energy he put into literature would inevitably led him to being an unqualified ruler of his country

The situation was urgent, but Li Yu's country was not necessarily to be wiped out by the Northern Song Dynasty, because Human effort is always the decisive factor. During the Three Kingdoms period, three kingdoms of $\mathrm{Wu}$, Shu, and Wei stood side by side in China. In the period of the South and North Dynasties, the South Dynasties and the North Dynasties confronted each other across the Yangzi River. These are examples before Li Yu. After Li Yu, Zhu Yuanzhang of the Ming Dynasty revolted from the South marched to the north to conquer the Yuan Dynasty, and the Kuomintang rose in the South and unified the whole nation, etc.. If Li Yu were hard, he could not have been a emperor who lost his throne and country. If Li Yu were hard-working, he could have not only expanded his territory but also destroyed the Northern Song Dynasty. Some people think that $\mathrm{Li} \mathrm{Yu}$ lost his country because of his poetry creation. There is really a certain truth in it. There have been a lot of emperors in China, but few can be regarded as famous writers. 


\section{Conclusion}

$\mathrm{Li} \mathrm{Yu}$ died at the age of 42. His life was short and tragic. But Li Yu's contribution to Chinese literature and Chinese culture was great. We should not judge a person by his success or failure. The Chinese regard morals, meritorious service, and literature as the three immortals. We can look at the meritorious service as political achievements, morals and literature as cultural achievements. This showed that Chinese ancient people attached much importance to culture. In modern China, Jiang Zemin put forward the important thought of Three Represents, which means that the Communist Party of China is the representative of advanced productive forces, advanced culture and the fundamental interests of the broad masses of the people. Therefore, the Communist Party of China attaches great importance to cultural construction. The people who had always sneered at $\mathrm{Li} \mathrm{Yu}$ were political and military heroes. To these people to conquer the world and to gain power were regarded as the greatest cause and they despise cultural construction. In a sense, the significance of cultural construction is much higher than the political and military achievements. This is why poets think a lot of themselves. Qu Yuan, Li Bai, Du Fu, Lu Xun and so on have a clear understanding of their own value. Li Yu's time was over one thousand years from now. When we think of and evaluate the ancient people from a distance, we can see that $\mathrm{Li} \mathrm{Yu}$ is immortal. People who defeated $\mathrm{Li} \mathrm{Yu}$, killed Li Yu have become the passers-by in history. History is fair. Time is the greatest judge. Li Yu's misfortune and humiliation, to some extent, was compensated for by his high literary achievements.

\section{References}

[1] Guowei Wang. Renjiancihua [M ]. Shanghai ancient books publishing house, 1998.1

[2] Song Liu, Rui Geng. On Li Yu's dream images [J]. Social Science Journal of Xiangtan University, 2000, 4 (2)

[3] Yusheng Long. On the two emperors' Ci [A]. Proceedings of Yusheng Long on Ci[C]. Shanghai: Shanghai Ancient Books Press, 1997

[4] Tuo Tuo. The history of the Song Dynasty [M]. Beijing: China Publishing House, 1985

[5] China unofficial histories integrated [M]. Chengdu: Bashu publishing house, 1993

[6] Wu Wenzhi. The full Song poetry [M]. Nanjing: Jiangsu Ancient Books Press, 1998

[7] Ma Ling. South Tang history [M]. Wenyuange books. Shanghai: Shanghai Ancient Books Press, 1987

[8] Zheng Zhenduo. Illustrations of the history of Chinese literature[M]. People's Literature Publishing House, 1982.

[9] Ji Zuoliang. Appreciation on Ci of Tang and Five Dynasties[M]. Anhui literature and Art Publishing House, 1989.201

[10]Zhong Weidong. Early Ci of Li Yu [J]. Journal of Qiqiihar Teachers College, 1994, (3). 